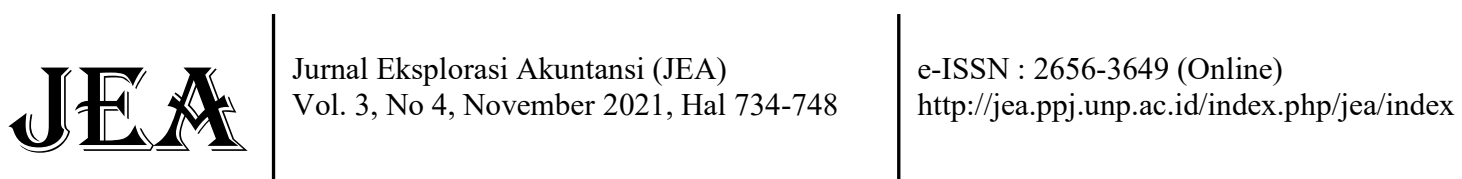

\section{Pengaruh Tekanan, Peluang, Rasionalisasi dan Nilai Etika terhadap Intensi Kecurangan Karyawan: Studi Kasus pada Perusahaan BUMN}

\author{
Riski Hildayani ${ }^{1 *}$, Vanica Sherly ${ }^{2}$ \\ 1,2 Fakultas Ekonomi, Universitas Negeri Padang \\ *Korespondensi:@kikihildayani7@gmail.com
}

\begin{abstract}
This study aims to examine the effect of pressure, opportunity, rationalization, and ethical values on employee fraud intentions in BUMN in Indonesia. This type of research is classified as survey research with a quantitative approach. The population in this study were employees of BUMN in Indonesia. The research sample was determined by purposive sampling method in order to obtain a sample of 65 employees in BUMN. The type of data used is primary data obtained from questionnaires. Data analysis using multiple regression, employee fraud intention as the dependent variable and pressure, opportunity, rationalization and ethical values as independent variables. The result of this study indicate that: (1) pressure has no positive significant effect on employee fraud intention, so hypothesis 1 is rejected, (2) opportunity has a significant positive effect on employee fraud intention, sho hypothesis 2 is accepted, (3) rationalization has a significant positive effect on employee fraud intention employee fraud, so hypothesis 3 is accepted, (4) ethical values do not have a significant negative effect on employee fraud intentions, so hypothesis 4 is rejected. So, it can be concluded that opportunity and rationalization have a significant influence on employee fraud intentions in BUMN.
\end{abstract}

Keywords: Fraud; Pressure; Opportunity; Rationalization; Ethical Value; Employee; BUMN.

How to cite (APA $6^{\text {th }}$ style)

Hildayani, R \& Sherly, V. (2021). Pengaruh Tekanan, Peluang, Rasionalisasi, dan Nilai Etika tehadap Intensi Kecurangan Karyawan : Studi Kasus pada Perusahaan BUMN. Jurnal Eksplorasi Akuntansi (JEA), 3 (4), 734-748.

\section{PENDAHULUAN}

Fraud merupakan perbuatan menyimpang dari norma yang berlaku yang dilakukan oleh orang pribadi atau sekelompok orang demi meraup keuntungan sepihak dan biasanya merugikan orang banyak. Berdasarkan hasil survey yang dilakukan oleh Association of Cerified Fraud Examiners Indonesia (ACFE) pada tahun 2016, fraud yang paling banyak dilakukan di Indonesia adalah korupsi. ACFE Indonesia menjelaskan prosentase kegiatan fraud yang dilakukan di Indonesia adalah sebesar 77\% korupsi, 19\% penyalagunaan aktiva atau kekayaan Negara dan perusahaan dan sisanya pada kecurangan laporan keuangan.

Korupsi merupakan suatu tindakan merugikan yang sering terjadi pada pejabat Negara \& Indonesia (Pristiyanti, 2012). Korupsi sendiri telah menjadi hal yang lumrah di lingkungan pemerintahan baik pusat maupun daerah. Fraud jenis ini umumnya banyak terjadi di Negara 
berkembang yang penegakan hukumnya lemah dan masih kurang kesadaran akan tata kelola yang baik sehingga faktor integritasnya masih dipertanyakan (Kusumawardhani, 2013).

BUMN merupakan bentuk usaha korporasi yang didirikan di bawah naungan pemerintah dengan tujuan utama menjalankan fungsi pemerintahan yaitu agen bagi pembangunan ekonomi. BUMN adalah salah satu pelaku kegiatan ekonomi yang mempunyai peranan penting dalam penyelenggaraan perekonomian nasional dengan tujuan mewujudkan kesejahteraan masyarakat (Setiawan, 2016). Tetapi faktanya tidak sedikit karyawan dari Badan Usaha Milik Negara (BUMN) terlibat kasus keuangan yang mengarah pada tindakan fraud. Hal ini, tentu saja merugikan banyak pihak terutama kesejahteraan masyarakat. Dalam kasus yang terjadi pada Krakatau steel, Direktur pada perusahaan ini ditetapkan sebagai tersangka penerima suap kasus pengadaan kebutuhan barang dan peralatan di Krakatau steel (Upperline.id, 2019). Kasus lain yang baru-baru ini terjadi yaitu kasus penggunaan antigen bekas yang dilakukan oleh oknum pegawai dan direksi di PT Kimia Farma Apotek. Dari kecurangan yang mereka lakukan ini diduga meraup keuntungan $\mathrm{Rp} 1,8$ milyar dari penggunaan alat tes antigen bekas dan aksi ini diduga telah terjadi sejak Desember 2020 dan dilakukan terhadap 9.000 orang (Detik.com, 2021).

Teori yang digunakan dalam banyak studi tentang fraud adalah teori konseptual yang diusung oleh Dr. Donald R. Cressey (1953). Dalam penelitian (Roden, et al., 2016) menyimpulkan bahwa seseorang yang dipercaya dalam jabatannya memungkinkan melakukan pelanggaran ketika mereka terdampak dengan masalah finansial pribadi. Lebih lanjut, orang yang melakukan kecurangan menjadikan kewenangan jabatannya dan mengenal situasi sehari-hari dengan baik yang membuat kemungkinan mereka menyesuaikan diri dan sebagai orang yang dipercaya untuk memanfaatkan anggaran yang telah dipercayakan. Tekanan merupakan motivasi untuk melakukan fraud. Pada umumnya, tekanan biasanya disebabkan karena beberapa faktor, diantaranya adalah gaya hidup yang berlebihan, kebutuhan yang harus dipenuhi sementara keuangan tidak memadai serta sifat tamak dan selalu merasa kurang yang ada pada diri seseorang (Adelin, dkk., 2013). Tekanan tidak hanya disebabkan oleh hal di atas, Menurut Lister (2007) dalam (Said, et al., 2017); ada pula tekanan dari pekerjaan berupa target dari perusahaan yang harus dipenuhi demi kepentingan finansial perusahaan dan tekanan eksternal berupa harapan pasar yang harus dipenuhi serta persyaratan perjanjian kepada lembaga keuangan yang harus ditepati.

Peluang adalah salah satu faktor seseorang melakukan fraud. Menurut (Trisna Dewi, et al., 2018); pelaku fraud biasanya tergolong pribadi yang cerdas karena dapat memanfaatkan kesempatan yang ada demi keuntungan diri sendiri. Dengan adanya kesempatan, maka pelaku fraud bisa dengan sangat leluasa melakukan tindakan tidak terpuji tersebut. Pelaku biasanya menggunakan posisi atau jabatan mereka sebagai orang yang dipercaya perusahaan untuk memperdaya orang lain maupun perusahaan ketika dihadapkan dengan situasi yang memungkinkan mereka melakukan kecurangan (Hasuti, et al., 2020). Selain itu, kurangnya pengawasan dan sistem pengendalian internal yang lemah, maka bisa saja pada realitanya para pelaku ini tidak ada niat untuk melakukan fraud, menjadikan posisi dan jabatannya sebagai peluang untuk melakukan fraud (Zahara, 2017).

Rasionalisasi adalah upaya pembenaran terhadap tindakan kecurangan yang terjadi karena dianggap sebagai tindakan etis pada lingkungan tertentu. Misalnya, tindakan membenarkan penggunaan aset dengan alasan gaji seorang karyawan dianggap rendah dibandingkan beban kerja. Sehingga, tindakan yang dilakukan tersebut dianggap tidak merugikan siapapun. Rasionalisasi bisa dikatakan poin yang palling sulit diukur seperti apa yang dinyatakan oleh (Sukirman, et al., 2013).

Upaya untuk meminimalisir kecurangan (fraud) terus dilakukan melalui audit internal dan eksternal. Namun, tidak ada jaminan kecurangan ( fraud) tidak terulang. Oleh sebab itu perlu disadari bahwa ada faktor lain yang ikut berperan dalam terjadinya fraud. (Said, et al., 
2017) mengungkapkan bahwa meskipun fraud triangle theory oleh Cressey telah didukung oleh regulator, konsep ini tidak cukup sebagai alat untuk mengamati, mencegah, dan menghindari fraud. Oleh karena itu, diperlukan integrasi poin lain ke dalam teori fraud triangle sebagai mekanisme pencegahan kecurangan (fraud).

Dalam hal ini poin yang perlu ditambahkan adalah nilai etika yang merupakan nilai dasar yang harus dimiliki oleh setiap orang. (Velasquez, 2006) menyatakan bahwa etika adalah edukasi yang menjadi barometer moral seseorang atau moral di lingkungan masyarakat. Etika juga menilai apakah barometer moral ini masuk akal atau tidak beserta alasan yang mendukung dalam menilai baik dan buruknya perilaku seseorang. Nilai etika sangat dibutuhkan oleh seorang karyawan demi menjaga nama baik dan professionalnya dalam bekerja. Pernyataan ini sesuai dengan penelitian yang dilakukan oleh (Pradipta, et al., 2019), Karyawan harus menanamkan nilai etika di dalam dirinya guna mencegah resiko penyimpangan atau penyalahgunaan jabatan dan wewenang. Bagian dari nilai etika yang dibutuhkan seorang karyawan adalah integritas. Integritas adalah sebuah perilaku etis dimana karyawan dituntut untuk bersikap professional dalam profesinya. Maka, dengan tidak adanya integritas di dalam diri seorang karyawan memungkinkan kecurangan itu dapat timbul (Lestari, et al., 2017).

Beberapa penelitian terdahulu menjelaskan hubungan fraud triangle theory dengan kecurangan karyawan. (Said, et al., 2017) menemukan bahwa dua poin fraud triangle theory yaitu, rasionalisasi dan peluang, berhubungan positif dengan kecurangan karyawan. Ini menyiratkan bahwa untuk meminimalkan kecurangan karyawan, industri perbankan harus mengurangi peluang dan rasionalisasi negatif karyawan melalui pengendalian internal yang kuat. Sedangkan penelitian yang dilakukan oleh (Sujeewa, et al,, 2018) menunjukkan hasil bahwa penting bagi auditor dan akuntan forensik untuk mempertimbangkan semua macam fraud untuk lebih memahami mengapa kecurangan dilakukan dan juga harus dianggap sebagai perpanjangan dari fraud triangle theory yang mencakup motivasi, etika, dan kemampuan. Kedua penelitian ini menambahkan nilai etika dalam fraud triangle theory untuk menilai apakah etika berpengaruh terhadap timbulnya kecurangan karyawan. sebelumnya yang juga memasukkan nilai etika sebagai salah satu faktor seseorang melakukan fraud. Hasil penelitian (Said, et al., 2017) menunjukkan bahwa nilai etika berhubungan negatif dengan kecurangan karyawan yang mana berarti nilai etika yang tinggi sangat penting untuk mengurangi kecurangan karyawan.

Keterbatasan dari penelitian sebelumnya terletak pada objek penelitian. Pada penelitian yang dilakukan (Sujeewa, et al., 2018); mereka hanya berfokus untuk memperluas pengetahuan auditor eksternal dan akuntan forensik saja. Sedangkan pada penelitian yang dilakukan (Said, et al., 2017); berfokus pada karyawan yang bekerja pada industri perbankan di Malaysia. Penelitian yang dilakukan (Zahara, 2017) juga hanya berfokus pada narapidana korupsi di Lembaga Permasyarakatan Kelas II A Kota Pekanbaru. Penelitian ini mengacu pada penelitian yang telah dilakukan oleh (Said, et al., 2017). Perbedaan dari penelitian sebelumnya ialah objek penelitian. Penulis memilih BUMN sebagai objek penelitian karena fenomena kecurangan di BUMN dan gap peneliti sebelumnya.

Berdasarkan fenomena di atas penulis merumuskan masalah apakah tekanan, peluang, rasionalisasi, dan nilai etika berpengaruh terhadap timbulnya kecurangan karyawan. Penelitian ini bertujuan untuk memberikan kontribusi literature dengan menambah nilai etika ke dalam triangle fraud theory. Dengan mengetahui bertambahnya literature tentang faktorfaktor terjadinya kecurangan, diharapkan dapat meningkatkan kesadaran manajemen dan pimpinan perusahaan khususnya Badan Usaha Milik Negara untuk membuatkan kebijakan/ keputusan pencegahan fraud dengan tepat. 


\section{REVIEW LITERATUR DAN HIPOTESIS Teori Atribusi}

Teori atribusi ini mempelajari proses bagaimana seseorang mengintepretasikan suatu peristiwa, alasan, atau sebab perilakunya. Teori ini dikembangkan oleh Fritz Heider yang beragumentasi bahwa perilaku seseorang ditentukan oleh kombinasi antara kekuatan internal, yaitu faktor-faktor yang berasal dari luar, seperti kesulitan dalam pekerjaan atau keberuntungan. Berdasarkan hal tersebut, seseorang akan termotivasi untuk memahami lingkungannya dan sebab-sebab kejadian tertentu (Lubis, 2010) Dari perilaku dapat dianalisa karakteristik dan watak seseorang tersebut jika menghadapi situasi seperti adanya peluang untuk melakukan kecurangan (Lestari, et al., 2017).

Maka dapat disimpulkan bahwa tindakan kecurangan yang dilakukan seseorang dapat diminimalisir dengan memperkuat kekuatan internal seseorang. Kecurangan yang disebabkan oleh atribut penyebab dalam hal ini penyebab kecurangan adalah pengendalian internal yang lemah dan pengawasan yang dilakukan oleh pimpinan (Adelin, et al., 2013) bisa dikendalikan karena kekuatan internal tersebut. Bahkan jika kedua kekuatan internal dan eksternal berjalan dengan baik, maka kecurangan bisa dikendalikan dengan baik. Jika pengendalian internal di dalam suatu perusahaan tersebut kuat dan efektif, maka dapat meminimalisir kecendrungan kecurangan (Pasaribu, et al., 2017).

\section{Kecurangan Karyawan}

Salah satu kecurangan kerah putih yang paling umum adalah kecurangan karyawan dalam pekerjaannya. Hal ini dilakukan untuk memperkaya diri sendiri dengan membuat gejala kecurangan secara sengaja. Ekcurangan ini dapat berdampak pada tatanan sosial dan ekonomi (Kumar, et al., 2018). Menurut Sie Infokum dalam (Putra, 2010), karyawan melakukan kecurangan bertujuan untuk mendapatkan keuntungan pribadi. Tindak kecurangan adalah tindakan yang melanggar nilai-nilai etika yang dapat merusak moral mengingat masyarakat Indonesia sendiri nilai-nilai etika berasal dari spiritual yang kuat menyakininya sebagai pedoman agar terhindar dari perilaku yang merugikan khalayak banyak (Urumsah, et al., 2018). Menurut Simanjuntak (2008) dalam (Putra, 2010) mengklasifikasikan kecurangan menjadi 4 golongan berdasarkan yaitu: pencatatan, frekuensi, konspirasi, dan keunikan.

\section{Faktor Penyebab Fraud}

Cressey (1953) yang menyimpulkan bahwa terdapat kondisi yang menyebabkan fraud di perusahaan yaitu tekanan, peluang, dan rasionalisasi (Romney \& Steinbart, 2014). Berikut penjelasan dari ketiga kondisi penyebab fraud:

a. Tekanan

Tekanan merupakan suatu dorongan seseorang dapat melakukan fraud. Tekanan dapat diakibatkan oleh berbagai hal termasuk tekanan yang bersifat finansial dan non finansial. Faktor finansial muncul karena keinginan untuk memiliki gaya hidup yang cukup secara materi. Sedangkan faktor non finansial muncul karena sifat dasar manusia yang serakah bisa jadi memberikan tekanan internal sehingga mendorong seseorang melakukan tindakan fraud (Sukirman dan Sari, 2013 dalam (Pasaribu, dkk., 2018).

b. Peluang

Menurut Rukmawati (2011) dalam (Kennedy, dkk., 2017), peluang menyebabkan pelaku secara leluasa dapat menjalankan aksinya yang disebabkan oleh pengendalian internal yang lemah, ketidakdisplinan, kelemahan dalam mengakses informasi, tidak ada mekanisme audit, dan sikap apastis. Peluang menjadi salah satu faktor paling penting. Tanpa adanya peluang, maka karyawan akan sulit melakukan tindakan kecurangan tanpa tertangkap. Peluang dapat berupa kepercayaan yang telah diberikan 
pimpinan kepada karyawan namun disalahgunakan untuk melakukan kecurangan (Sujeewa, et al., 2018). Jabatan dan kekuasaan juga menjadi faktor terjadinya fraud misalnya pengaruh seorang pimpinan di perusahaan tersebut. Seorang manajer dapat menjadikan karyawannya perantara atau alat untuk melakukan kecurangan tetapi mayoritas pimpinan tidak akan melakukan itu karena mereka mempunyai kesempatan tanpa harus menggunakan karyawannya melainkan mengandalkan jabatan dan wewenang (Wicaksono, et al., 2016).

c. Rasionalisasi

Rasionalisasi merupakan tindakan mencari pembenaran sebelum melakukan tindakan fraud dan dijadikan motivasi untuk melakukan tindakan tidak terpuji tersebut. Rasionalisasi dapat terjadi karena pelaku fraud merasa tindakannya legal walaupun tindakan tersebut dianggap tidak etis. Jika seseorang tersebut terbukti melakukan fraud, maka dia akan mencari alasan agar tidak dipersalahkan. Faktor-faktor yang mendorong seseorang mencari pembenaran atas tindakannya melakukan fraud, antara lain (Pamungkas, 2014):(1) Mencontoh atasan atau teman sesama karyawan, (2) Merasa sudah berbuat banyak untuk organisasi atau perusahaan, (3) Menganggap bahwa yang diambil tidak seberapa, (4) Dianggap hanya sekedar meminjam, pada waktunya akan dikembalikan.

Dari penjelasan diatas maka dapat disimpulkan bahwa kecurangan karyawan disebabkan adanya tekanan, baik tekanan dari lingkungan maupun tekanan dari dalam dirinya sendiri. Tentu saja, munculnya keinginan melakukan tindakan illegal itu didukung oleh lemahnya pengendalian internal dalam perusahaan serta pengawasan atas jobdesk masing-masing divisi memungkinkan adanya kesempatan tanpa memikirkan dampak buruknya terhadap perusahaan dan kepentingan publik. Akibatnya, mereka yang melakukan tindakan kecurangan ini berupaya mencari pembenaran atas kegiatan yang tentu saja akan merugikan banyak pihak.

\section{Nilai Etika}

Menurut (Lubis, 2010), Nilai mengandung suatu unsur pertimbangan dalam pengertian bahwa nilai mengemban gagasan-gagasan seorang individu mengenai apa yang benar, baik, atau diinginkan. Dalam mempelajari perilaku dalam organisasi, nilai dinyatakan penting karena nilai meletakkan dasar untuk memahami sikap serta motivasi dan karena nilai memengaruhi persepsi manusia. Nilai etika muncul dalam kepribadian seseorang, yang bertujuan agar setiap kegiatan kecurangan dapat dicegah dengan pemikiran dan kepercayaan seseorang tentang benar atau salah (Sujeewa, et al., 2018). Karyawan sangat membutuhkan nilai etika untuk menjaga nama baik dan sikap profesionalnya terhadap pekerjaan, maka karyawan akan terlindungi dari tindakan yang melanggar norma atau penyalahgunaan wewenang (Pradipta, et al., 2019).

Seseorang yang melanggar norma atau penyalahgunaan wewenang termasuk kedalam perilaku tidak etis. Perilaku tidak etis ikut andil dalam pengaruh efektivitas pengendalian internal, kepuasan karyawan, dan asimetri informasi (Nurlaeliyah, et al., 2017).

\section{Pengembangan Hipotesis}

Tekanan menjadi salah satu motivasi seseorang dalam melakukan kecurangan. tekanan muncul dari individu dimana mereka mempunyai berbagai macam kebutuhan yang dapat mempengaruhi perilaku mereka. Salah satunya kebutuhan fisiologis bersifat finansial (Marliani, et al., 2015). Tekanan dapat mempengaruhi kecurangan karyawan ini disebabkan bahwa karyawan mengalami desakan baik dari pribadinya maupun lingkungannya untuk mencapai target yang diinginkan.

H1: Tekanan berpengaruh positif terhadap intensi kecurangan karyawan. 
Teori atribusi menjelaskan bahwa perilaku atau tindakan seseorang yang diberikan kepercayaan melalui jabatan atau posisi yang tinggi dipengaruhi oleh atribut penyebab. Maka, tindakan kecurangan bisa saja dipengaruhi oleh pengendalian internal dan pengawasan seorang pimpinan (Adelin, et al., 2013).

Semakin tinggi peluang yang dimiliki karyawan maka semakin tinggi pula indikasi kecurangan itu terjadi. Hal ini dapat terjadi disebabkan oleh pengendalian internal di dalam perusahaan tersebut tergolong lemah serta kurangnya pengawasan dan penyelewengan wewenang.

H2: Peluang berpengaruh positif terhadap intensi kecurangan karyawan.

Teori Segitiga Kecurangan yang dikembangkan oleh Cressey (1953) dalam menjelaskan bahwa ada tiga keadaan yang cenderung selalu ada saat terjadinya kecurangan di antaranya tekananm peluang, dan rasionalisasi. Rasionalisasi adalah perilaku membenarkan tindakan yang dianggap merugikan banyak pihak. Rasionalisasi muncul dalam pemikiran seseorang yang menyakini bahwa tindakannya benar dengan alasan yang cenderung dibuatbuat.

H3: Rasionalisasi berpengaruh positif terhadap intensi kecurangan karyawan.

Teori atribusi menjelaskan bahwa perilaku atau tindakan seseorang disebabkan oleh atribut penyebab. Dalam hal ini, penyebab perilaku seseorang didasari oleh nilai etika yang diyakininya. Semakin tinggi seorang karyawan dan perusahaan memerhatikan nilai etika, maka semakin kecil kemungkinan timbulnya kecurangan pada karyawan. Hal ini disebabkan oleh watak seseorang yang menilai baik dan buruk berdasarkan lingkungan dan standar moral yang berlaku di masyarakat.

H4: Nilai Etika berpengaruh negatif terhadp intensi kecurangan karyawan.

\section{METODE PENELITIAN \\ Jenis Penelitian dan Sumber Data}

Penelitian ini menggunakan jenis penelitian survey dengan pendekatan kuantitatif. Populasi yang digunakan dalam penelitian ini adalah perusahaan BUMN yang ada di Indonesia. Dari situs BUMN terdapat 9 klaster industri terdiri dari klaster jasa asuransi dan dana pension, energi minyak dan gas; mineral dan batubara; jasa keuangan, jasa logistic, jasa kesehatan, jasa infrastruktur, industri pangan dan pupuk; jasa pariwisata dan pendukung, serta jasa telekomunikasi dan media dengan menggunakan metode purposive sampling. Penulis memilih sampel dengan mengambil perwakilan dari masing-masing klaster kemudian, sampel yang dipilih adalah karyawan BUMN yang bersedia mengisi kuesioner online sehingga penulis mendapatkan 65 orang karyawan untuk dijadikan sampel. Sumber data yang digunakan dalam penelitian ini adalah data primer yang diperoleh secara langsung dari sumber asli secara khusus dikumpulkan untuk menjawab pertanyaan penelitian.

\section{Metode Pengumpulan Data}

Teknik pengumpulan data dikumpulkan dengan survey kuesioner secara online menggunakan aplikasi google form yang disebar melalui media sosial berupa link. Hasil kuesioner dapat dilihat oleh penulis melalui akun pribadi google form penulis.Sub bab ini terdiri atas tipe penelitian, populasi dan sampel, jenis dan teknik pengumpulan data, dan pengujian hipotesis, serta definisi operasional variabel penelitian. Metode penelitian juga memuat teknis analisis data yang digunakan untuk menguji hipotesis penelitian. 


\section{Variabel dan Instrumen Penelitian}

Variabel penelitian ini terdiri dari variabel dependen (Y) yaitu kecurangan karyawan dan variabel independen (X) yaitu tekanan, peluang, rasionalisasi, dan nilai etika. Instrument penelitian ini adalah kuesioner menggunakan skala likert dengan lima jawaban alternative, masing-masing diberi skor yaitu: SS (Sangat Setuju), S (Setuju), KS (Kurang Setuju), TS (Tidak Setuju), dan STS (Sangat Tidak Setuju). Rancangan kuesioner ini mengadaptasi dan memodifikasi dari penelitian yang dilakukan Said et al., (2017).

\section{HASIL PENELITIAN}

\section{Uji Statistik Deskriptif}

Analisis deskriptif menggambarkan mengenai data yang dilihat dari rata-rata (mean), standar deviasi, varian, maksimum, dan minimum pada setiap variabel yang diteliti yaitu tekanan, peluang, rasionalisasi, dan nilai etika (X) dan kecurangan karyawan (Y). Tabel 1 berikut menyajikan hasil analisis masing-masing variabel.

Tabel 1

Tabel Uji Statistik Deskriptif

\begin{tabular}{ccccccc}
\hline & N & Min & Max & Mean & Std. Devia & Variance \\
\hline Y & 65 & 5 & 20 & 9,75 & 3,509 & 12,313 \\
X1 & 65 & 9 & 24 & 17,88 & 3,352 & 11,238 \\
X2 & 65 & 17 & 30 & 26,98 & 2,934 & 8,609 \\
X3 & 65 & 11 & 28 & 18,43 & 3,513 & 12,343 \\
X4 & 65 & 13 & 29 & 22,58 & 2,738 & 7,497 \\
\hline
\end{tabular}

Sumber : Data Primer yang diolah pada tahun 2021

Dari tabel di atas dapat diketahui bahwa hasil deskriptif variabel kecurangan karyawan (Y) diketahui bahwa jumlah responden dalam penelitian ini adalah 65 responden $(\mathrm{N})$, dari 65 responden ini nilai terendah (minimum) dan tertinggi (maksimum) yaitu sebesar 5 dan 20. Rata-rata nilai dari 65 responden atau mean sebesar 9,75 dengan standar deviasi sebesar 3,509 dan varian 12,313.

Variabel X1 yaitu tekanan diketahui jumlah responden dalam penelitian ini adalah 65 responden $(\mathrm{N})$, dari 65 responden ini nilai terendah (minimum) dan tertinggi (maksimum) yaitu sebesar 9 dan 24. Rata-rata nilai dari 65 responden atau mean sebesar 17,88 dengan standar deviasi 3,352 dan varian 11,235. Variabel X2 (peluang) memiliki nilai terendah (minimum) dan nilai tertinggi (maksimum) yaitu sebesar 17 dan 30. Dan mean sebesar 26,98 dengan standar deviasi sebesar 2,934.

Variabel X3 (rasionalisasi) memiliki nilai terendah (minimum) dan nilai tertinggi (maksimum) yaitu sebesar 11 dan 28. Sedangkan mean sebesar 18,43 dengan standar deviasi sebesar 3,513. Terakhir yaitu variabel $\mathrm{X} 4$ yaitu nilai etika memiliki nilai terendah dan tertinggi sebesar 13 dan 29. Dengan mean sebesar 2,738 dan varian 7,497.

\section{Uji Normalitas}

Uji normalitas digunakan untuk menguji apakah distribusi data mengikuti atau mendekati distribusi normal, data yang baik adalah data yang pola distribusinya normal. Uji normalitas dapat dilakukan dengan metode Kolmogorav-Sminorv Test. 
Tabel 2

Uji Normalitas

\begin{tabular}{llr}
\hline \multicolumn{2}{c}{ Unstandardized Residual } \\
N & Mean & 65 \\
& Std. Deviation & .0000000 \\
Most Extreme Differences & Absolute & 2.52457769 \\
& Positive & .056 \\
& Negative & .056 \\
Test Statistic & & .054 \\
Asymp. Sig. (2-tailed) & & .056 \\
\hline
\end{tabular}

Sumber: Data primer yang diolah tahun 2021

Berdasarkan tabel di atas terlihat bahwa hasil uji normalitas menunjukkan level signifikansi lebih besar dari $\alpha(\alpha=0,005)$ yaitu $0,200>0,005$ yang berarti bahwa data terdistribusi secara normal.

\section{Uji Multikolonieritas}

Menurut (Sujarweni, 2020) pengujian dilakukan untuk mengetahui ada tidaknya variabel independen yang memiliki kemiripan antar variabel independen dalam suatu model. Kemiripan antar variabel independen akan mengakibatkan korelasi yang sangat kuat. Jika VIF yang dihasilkan diantara 1-10 maka terjadi multikolenearitas. Sedangkan jika VIF di atas 10 maka tidak terjadi multikolonealiritas.

Tabel 3

\begin{tabular}{lrl}
\multicolumn{3}{c}{ Uji Multikolonieritas } \\
\hline \multicolumn{1}{c}{ Model } & Tolerance & VIF \\
\hline (Constant) & & \\
Tekanan & .627 & 1.595 \\
Peluang & .920 & 1.087 \\
Rasionalisasi & .609 & 1.642 \\
Nilai Etika & .651 & 1.536 \\
\hline ber: Data primer yang diolah, 2021
\end{tabular}

Tabel 3 menunjukkan bahwa semua variabel dependen memiliki nilai (VIF) lebih besar dari tolerance. Dengan demikian dapat dikatakan tidak terdapat korelasi variabelvariabel bebas antara satu dengan yang lainnya, atau variabel independen pada penelitian ini bebas multikolonieritas.

\section{Uji Heteroskedastisitas}

Uji heterokedastisitas bertujuan untuk menguji apakah dalam sebuah model regresi terjadi ketidaksamaan varians dari residual atas satu pengamatan ke pengamatan yang lain. Jika varians dari residual suatu pengamatan ke pengamatan lain tetap, maka disebut homokedastisitas dan jika berbeda maka disebut heteroskedisitas. Untuk mendeteksi adanya heteroskedastisitas pada penelitian ini menggunakan uji Park. Pengujian ini membandingkan siginifikan dari uji ini apabila hasilnya sig $>0,05$ atau 5\%. Jika signifikan di atas 5\% maka disimpulkan model regresi tidak mengandung adanya heteroskedastisitas. Adapun hasil pengujian dapat dilihat pada tabel berikut. 
Tabel 4

Uji Heteroskedatisitas

\begin{tabular}{lrrrrr}
\hline \multicolumn{1}{c}{ Model } & Unstandaried B & $\begin{array}{c}\text { Std. Coeff. } \\
\text { Error }\end{array}$ & $\begin{array}{c}\text { Std. Coeff. } \\
\text { Beta }\end{array}$ & \multicolumn{1}{l}{ t } & \multicolumn{1}{l}{ Sig } \\
\hline (Constant) & -3.432 & 3.501 & & -.980 & .331 \\
Tekanan & -.101 & -.113 & -.141 & -.894 & .375 \\
Peluang & .060 & .102 & .077 & .587 & .559 \\
Rasionalisasi & .191 & .111 & .277 & 1.711 & .092 \\
Nilai Etika & .021 & .153 & .022 & .138 & .890 \\
& & & & &
\end{tabular}

Sumber : Data primer yang diolah tahun 2021

Berdasarkan Tabel 4 dapat dilihat bahwa hasil perhitungan masing-masing variabel menunjukkan level sig $>0,05$ yaitu $0,375>0,05$ untuk variabel tekanan, 0,559>0,05 untuk variabel peluang, $0,092>0,05$ untuk variabel rasionalisasi, dan $0,890>0,05$ untuk variabel nilai etika. Sehingga penelitian ini bebas dari gejala heterokedatisitas dan layak untuk diteliti.

\section{Pengujian Hipotesis}

Analisis regresi linier berganda digunakan dalam penelitian ini dengan tujuam untuk mengetahui ada tidaknya pengaruh variabel bebas terhadap variabel terikat. Perhitungan statistik dalam analisis regresi linear berganda yang digunakan dalam penelitian ini adalah dengan menggunakan bantuan program komputer SPSS for Windows. Ringkasan hasil pengolahan data dengan menggunakan program SPSS tersebut adalah sebagai berikut

Tabel 5

Uji Regresi Berganda

\begin{tabular}{lrrrrr}
\hline \multicolumn{1}{c}{ Model } & $\begin{array}{c}\text { Unstd. } \\
\text { Coeff. B }\end{array}$ & Coeff. Std. E & Std. Coeff. B & T & Sig \\
\hline (Constant) & -2.791 & 3.464 & & -.806 & .424 \\
Tekanan & -.191 & .123 & .183 & 1.561 & .124 \\
Peluang & .423 & .110 & .374 & 3.844 & .000 \\
Rasionalisasi & .479 & .120 & .480 & 4.012 & .000 \\
Nilai Etika & -.162 & .162 & -.114 & -.996 & .323 \\
\hline
\end{tabular}

Sumber: Data primer yang diolah tahun 2021

Berdasarkan tabel di atas dapat dianalisis model estimasi sebagai berikut.

$\mathrm{Y}=-2,791+0,191 \mathrm{X} 1+0,423(\mathrm{X} 2)+0,479(\mathrm{X} 3)-0,162+\mathrm{e}$

Keterangan:

$\mathrm{Y}=$ Kecurangan Karyawan (fraud)

$\mathrm{X} 1=$ Tekanan

$\mathrm{X} 2=$ Peluang

$\mathrm{X} 3=$ Rasionalisasi

$\mathrm{X} 4=$ Nilai Etika 


\section{Uji Statistik F}

Uji statistik F untuk membuktikan secara simultan apakah terdapat pengaruh antara tekanan, peluang, rasionalisasi, dan nilai etika untuk menilai kecurangan karyawan di perusahaan BUMN di Indonesia. Dengan tingkat signifikan 5\% dan derajat kebebasan $\mathrm{df} 1=4$ dan $\mathrm{df} 2=60$ maka tabel didapat $\mathrm{F}(4 ; 60)=2,53$. Dalam perhitungan diperoleh nilai $\mathrm{F}$ hitung besar dari $\mathrm{F}$ tabel, yaitu 13,971 $>2,53$. Sedangkan jika dilihat dari nilai probabilitas hitung adalah 0,000 yaitu $<0,05$ maka keputusannya menunjukkan bahwa secara simultan terdapat pengaruh antara tekanan, peluang, rasionalisasi, dan nilai etika untuk menilai kecurangan karyawan terhadap karyawan BUMN di Indonesia. Uji F dapat dilihat pada Tabel 6 berikut ini:

Tabel 6

Uji F

\begin{tabular}{lrrrrr}
\multicolumn{7}{c}{ Uji F } \\
\hline Model & Sum of Square & \multicolumn{1}{c}{ df } & Mean Square & \multicolumn{1}{c}{ F } & Sig \\
\hline Regressiom & 380.041 & 4 & 95.010 & 13.971 & $.000^{\mathrm{b}}$ \\
Residual & 408.020 & 60 & 7.800 & & \\
Total & 788.062 & 64 & & & \\
\hline
\end{tabular}

a. Dependent Variable: Kecurangan Karyawan

b. Predictors: (Constant), Nilai Etika, Peluang, Tekanan, Rasionalisasi

Sumber: Data primer yang diolah tahun 2021

Nilai $\mathrm{R}$ square sebesar 0,656 yang menunjukkan bahwa untuk menilai kecurangan karyawan (Y) di perusahaan BUMN di Indonesia dipengaruhi oleh variabel X1 (tekanan), X2 (peluang), X3 (rasionalisasi), dan X4 (nilai etika) sebesar 44,8\%, sisanya yaitu 55,2\% bahwa untuk menilai kecurangan karyawan di perusahaan BUMN di Indonesia dipengaruhi variabel lain yang belum diteliti dalam penelitian ini. Berikut Tabel 7 Uji koefisien determinasi bisa dilihat di bawah ini.

Tabel 7

Uji Koefisien Determinasi

\begin{tabular}{|c|c|c|c|c|}
\hline Model & $\mathbf{R}$ & R Square & $\begin{array}{l}\text { Adjusted R } \\
\text { Square }\end{array}$ & Std. Error \\
\hline 1 & $.694^{\mathrm{a}}$ & .482 & .448 & 2.608 \\
\hline
\end{tabular}

a. Predictors: (Constant), Nilai Etika, Peluang, Tekanan, Rasionalisasi

b. Dependent Variable: Kecurangan Karyawan

Sumber: Data primer yang diolah tahun 2021

\section{Uji Hipotesis (t-test)}

Uji t statistik (t-test) bertujuan untuk mengetahui hubungan yang signifikan dari masing-masing variabel bebas terhadap variabel terikatnya. Pengujian hipotesis secara parsial dilakukan dengan cara membandingkan nilai thitung dengan nilai tabel. Dalam penelitian ini diketahui bahwa $\mathrm{n}=65$ pada tingkat signifikansi $5 \%$. Pada tingkat kesalahan $(\alpha=0,05)$ dengan derajat bebas $(\mathrm{db})=\mathrm{n}-\mathrm{k}=65-4=61$ adalah 1,670 berdasarkan hasil analisis pada Tabel 5 maka dapat diketahui pengaruh variabel independen secara parsial terhadap variabel dependen adalah sebagai berikut :

\section{Pengujian Hipotesis 1}

Pengujian hipotesis dilakukan dengan membandingkan $t_{\text {hitung }}$ dengan nilai $t_{\text {tabel. }}$. Hipotesis diterima jika $t_{\text {hitung }}>t_{\text {tabel }}$ atau nilai sig $<0,05$. Nilai $t_{\text {tabel }}$ pada 0,05 adalah 
1,670. Untuk variabel tekanan $\left(\mathrm{X}_{1}\right)$ nilai $t_{\text {hitung }}$ adalah 1,561 dan nilai signifikansi adalah 0,124 . Dengan demikian dapat dikatakan bahwa $t_{\text {hitung }}<t_{\text {tabel }}$ yaitu $1,561<1,670$ atau nilai signifikansi $0,124>0,05$. Nilai koefisien $\beta$ dari variabel $X_{1}$ bernilai positif yaitu 0,191 . Hal ini menunjukkan bahwa penelitian ini tidak dapat membuktikan bahwa tekanan $\left(\mathrm{X}_{1}\right)$ berpengaruh signifikan positif terhadap intensi kecurangan karyawan. Dengan demikian hipotesis pertama $\left(\mathrm{H}_{1}\right)$ ditolak.

\section{Pengujian Hipotesis 2}

Pengujian hipotesis dilakukan dengan membandingkan thitung dengan nilai $t_{\text {tabel }}$ Hipotesis diterima jika $t_{\text {hitung }}>t_{\text {tabel }}$ atau nilai sig $<0,05$. Untuk variabel peluang $\left(\mathrm{X}_{2}\right)$

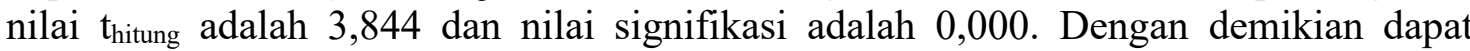
dikatakan bahwa $t_{\text {hitung }}>\mathrm{t}_{\text {tabel }}$ yaitu $3,844>1,670$ atau nilai signifikansi $0,000<0,05$. Nilai koefisien $\beta$ dari variabel $\mathrm{X}_{2}$ bernilai positif yaitu 0,423 . Hal ini menunjukkan bahwa penelitian ini membuktikan bahwa peluang $\left(\mathrm{X}_{2}\right)$ mempunyai pengaruh signifkan terhadap intensi kecurangan karyawan. Dengan demikian hipotesis pertama $\left(\mathrm{H}_{2}\right)$ diterima.

\section{Pengujian Hipotesis 3}

Pengujian hipotesis dilakukan dengan membandingkan $t_{\text {hitung }}$ dengan $t_{\text {tabel. }}$. Hipotesis diterima jika $t_{\text {hitung }}>t_{\text {tabel }}$ atau nilai sig $<0,05$. Untuk variabel rasionalisasi $\left(\mathrm{X}_{3}\right)$ nilai thitung adalah 4,012 dan nilai signifikasi adalah 0,000. Dengan demikian dapat dikatakan bahwa $t_{\text {hitung }}>t_{\text {tabel }}$ yaitu 4,012 $>1,670$ atau nilai signifikansi $0,000<0,05$. Nilai koefisien $\beta$ dari variabel $X_{3}$ bernilai positif yaitu 0,479 . Hal ini menunjukkan bahwa penelitian ini membuktikan bahwa rasionalisasi $\left(\mathrm{X}_{3}\right)$ berpengaruh signifikan positif terhadap intensi kecurangan karyawan. Dengan demikian hipotesis ketiga $\left(\mathrm{H}_{3}\right)$ diterima.

\section{Pengujian Hipotesis 4}

Pengujian hipotesis dilakukan uji satu sisi dengan membandingkan $t_{\text {hitung }}$ dengan nilai $t_{\text {tabel. }}$. Hipotesis diterima jika $t_{\text {hitung }}>t_{\text {tabel }}$ atau nilai $\operatorname{sig}<0,05$. Nilai $t_{\text {tabel }}$ pada 0,05 adalah 1,670. Untuk variabel Nilai etika $\left(\mathrm{X}_{4}\right)$ nilai $t_{\text {hitung }}$ adalah 0,996 dan nilai signifikasi adalah 0,323. Dengan demikian dapat dikatakan bahwa $t_{\text {hitung }}<t_{\text {tabel }}$ yaitu $0,996<1,670$ atau nilai signifikansi $0,323>0,05$. Nilai koefisien $\beta$ dari variabel $\mathrm{X}_{4}$ bernilai negatif yaitu $-0,162$. Hal ini menunjukkan bahwa penelitian ini membuktikan bahwa nilai etika $\left(\mathrm{X}_{4}\right)$ tidak berpengaruh signifikan negatif terhadap intensi kecurangan karyawan. Dengan demikian hipotesis keempat $\left(\mathrm{H}_{4}\right)$ ditolak.

\section{Pengaruh Tekanan terhadap Intensi Kecurangan Karyawan BUMN}

Hasil penelitian ini membuktikan bahwa hubungan antara tekanan tidak berpengaruh signifikan positif terhadap intensi kecurangan karyawan BUMN di Indonesia, yang artinya tekanan tidak memiliki pengaruh terhadap intensi kecurangan karyawan BUMN di Indonesia. Dimana rata-rata tingkat capaian responden sebesar $56,2 \%$ dengan kategori Kurang Baik. Hasil ini memberikan gambaran bahwa tekanan tidak mempengaruhi karyawan BUMN dalam melakukan kecurangan. Maka, dapat disimpulkan bahwa karyawan BUMN di Indonesia tidak menerima tekanan dari organisasinya maupun dari dalam dirinya

Hasil penelitian ini sejalan dengan penelitian yang dilakukan (Zahara, 2017) yang menunjukkan bahwa tekanan tidak berpengaruh signifikan positif terhadap 
kecurangan (fraud), hal ini menunjukkan bahwa sebagian besar karyawan melakukan tindakan kecurangan bukan karena adanya tekanan ekonomi melainkan pada umumnya karyawan yang melakukan kecurangan menganggap apa yang dilakukannya adalah hal yang umum yang biasa dilakukan dan tidak melanggar hukum dan kemanusiaan sehingga kecurangan kerap terjadi. (Said, Alam, Ramli, \& Rafidi, 2017) juga menemukan bahwa hubungan antara tekanan tidak berpengaruh signifikan positif terhadap kecurangan (fraud). Hasil ini tidak sejalan dengan teori yang dijelaskan Crassey, bahwa tekanan muncul dari individu dimana mereka mempunyai berbagai macam kebutuhan yang dapat mempengaruhi perilaku mereka.

\section{Pengaruh Peluang terhadap Intensi Kecurangan Karyawan BUMN}

Hasil penelitian ini memberikan bukti bahwa peluang berpengaruh signifikan terhadap intensi kecurangan karyawan BUMN di Indonesia. Hasil ini sesuai dengan teori atribusi menjelaskan bahwa perilaku atau tindakan seseorang yang diberikan kepercayaan melalui jabatan atau posisi yang tinggi dipengaruhi oleh atribut penyebab. Penelitian ini sejalan dengan penelitian yang dilakukan (Nurlaeliyah, dkk., 2017) yang menyatakan bahwa perilaku tidak etis dan kecenderungan kecurangan akuntansi disebabkan oleh pengendalian internal yang tepat. Karena ketika pengendalian internal lemah, hal itu dapat mempengaruhi seseorang melakukan kecurangan. Pendapat ini sejalan dengan hasil penelitian yang dilakukan (Mulia, dkk., 2017), keberadaan pengendalian internal mencegah seseorang untuk bertindak curang.

Dalam konteks perusahaan, keberadaan pengendalian internal bisa menjamin bahwa aset perusahaan bisa dijaga dengan lebih dibandingkan jika pengendalian internal tidak diadakan. (Pradipta \& Bernawati, 2019) juga menemukan dalam penelitiannya bahwa peluang berpengaruh negatif terhadap perilaku korupsi. Lemahnya pengendalian internal juga memicu peluang tersebut muncul. Penelitian (Lestari, dkk., 2017), (Zahara, 2017), dan (Kusuma, dkk., 2019) juga membuktikan bahwa peluang memiliki andil dalam tindakan seseorang melakukan kecurangan. Jadi, dapat disimpulkan bahwa kecurangan muncul karena adanya peluang yang timbul akibat lemahnya pengendalian internal di dalam perusahaan atau instansi tersebut.

\section{Pengaruh Rasionalisasi terhadap Intensi Kecurangan Karyawan BUMN}

Hasil penelitian ini membuktikan bahwa hubungan antara rasionalisasi berpengaruh signifikan terhadap intensi kecurangan karyawan BUMN di Indonesia. Hasil penelitian ini sejalan dengan teori Crassey yang menyatakan bahwa rasionalisasi adalah perilaku membenarkan tindakan yang dianggap merugikan banyak pihak. Hasil penelitian (Said, Alam, Ramli, \& Rafidi, 2017) menyatakan bahwa rasionalisasi merupakan sikap yang membuat seseorang membenarkan perilaku yang salah untuk dapat diterima. Hasil penelitian (Suryandari, dkk., 2019) juga menyatakan bahwa rasionalisasi merupakan pembenaran diri sendiri atau alasan yang salah untuk suatu perilaku yang salah.

Hasil penelitian ini tidak sejalan dengan penelitian yang dilakukan oleh (Hasuti, dkk., 2020) menyatakan bahwa rasionalisasi tidak berpengaruh terhadap perilaku korupsi yang mana korupsi adalah salah satu jenis tindakan kecurangan. Hasil penelitian yang dilakukan oleh (Hormati, dkk., 2019) tentang pengaruh rasionalisasi terhadap kecendrungan seseorang untuk melakukan kecurangan akuntansi menemukan bahwa rasionalisasi tidak berpengaruh signifikan terhadap kecenderungan seseorang 
untuk melakukan kecurangan dan rasionalisasi bukan alasan bagi ASN untuk bertindak curang.

\section{Pengaruh Nilai Etika terhadap Intensi Kecurangan Karyawan BUMN}

Hasil penelitian ini memberikan bukti bahwa nilai etika tidak berpengaruh signifikan terhadap intensi kecurangan karyawan BUMN di Indonesia. Hal ini menunjukkan bahwa atribut penyebab internal seperti nilai etika tidak mempengaruhi perilaku seseorang dalam melakukan kecurangan. Rata-rata tingkat capaian responden menunjukkan kategori cukup baik. Hal ini menggambarkan bahwa karyawan BUMN setuju bahwa nilai etika itu penting untuk dimiliki setiap orang tetapi nilai etika tidak mempengaruhi perilaku kecurangan karyawan pada perusahaan BUMN.

Hasil penelitian ini tidak sejalan dengan penelitian yang dilakukan (Said, Alam, Ramli, \& Rafidi, 2017) yang menemukan dalam penelitiannya bahwa nilai etika yang dianut secara individu dapat mempengaruhi karyawan untuk mematuhi kebijakan perusahaan yang telah ditetapkan manajemen dan menghindari terjadinya pelanggaran aturan oleh karyawan. Penelitian yang dilakukan (Sujeewa, et al., 2018) merekomendasikan untuk memasukkan nilai-nilai etika karyawan ke dalam fraud triangle theory untuk menanamkan nilai-nilai etis di kalangan karyawan. Penelitian yang dilakukan (Mulia, dkk., 2017) tentang budaya etis di sektor pemerintahan juga berpengaruh negatif terhadap tindakan fraud. Hal ini berarti, semakin tinggi budaya etis yang ada di lingkungan pemerintahan maka akan semakin rendah tingkat terjadinya fraud disektor pemerintahan.

\section{SIMPULAN DAN SARAN Simpulan}

Penelitian ini bertujuan untuk melihat apakah tekanan, peluang, rasionalisasi, dan nilai etika berpengaruh terhadap intensi kecurangan karyawan pada perusahaan BUMN di Indonesia. Berdasarkan hasil penelitian dan uji hipotesis yang telah dilakukan maka dapat disimpulkan sebagai berikut:

1. Tekanan tidak berpengaruh signifikan positif terhadap intensi kecurangan karyawan, sehingga hipotesis 1 ditolak.

2. Peluang berpengaruh signifikan positif terhadap intensi kecurangan karyawan, sehingga hipotesis 2 diterima

3. Rasionalisasi berpengaruh signifikan positif terhadap intensi kecurangan karyawan, sehingga hipotesis 3 diterima

4. Nilai etika tidak berpengaruh signifikan negatif terhadap intensi kecurangan karyawan, sehingga hipotesis 4 ditolak..

\section{Saran}

Berdasarkan hasil penelitian yang telah dikemukakan maka penulis memberikan saran kepada peneliti selanjutnya, diharapkan dapat melakukan penelitian yang lebih lanjut dengan menggunakan scenario pada kuesioner penelitian.

\section{DAFTAR PUSTAKA}

Adelin, V., \& Fauzihardani, E. (2013). Pengaruh Pengendalian Internal, Ketaatan pada Aturan Akuntansi dan Kecendrungan Terhadap Perilaku Tidak Etis. WRA , 259275. 
Hasuti, A. T., \& Wiratno, A. (2020). Pengaruh Budaya Organisasi, Tekanan, Kesempatan, dan Rasionalisasi terhadap Perilaku Korupsi. Jurnal Ekonomi, Bisnis, dan Akuntansi (JERA) , 113-122.

Hormati, G. A., Adechandra, D., Ashedicca, \& Pesudo. (2019). Pengaruh Tekanan. kesempatan, Rasionalisasi, dan Kemampuan terhadap Kecendrungan Aparatur Sipil Negara dalam Melakukan Kecurangan Akuntansi. 9.

Ikhsan, A., \& Ishak, M. (2008). Akuntansi Keprilakuan. Salemba Empat.

Kennedy, P. S., \& Siregar, L. S. (2017). Para Pelaku Fraud di Indonesia Menurut Survei Fraud Indonesia. Buletin Ekonomi FEUKI, 1-8.

Kumar, K., Bhattacharya, S., \& Richard E., H. (2018). Employee Perception of Organization Culture With Respect to Fraud-Where to Look and What to Look For. Pacific Accounting Review, 187-198.

Kusuma, I., Nurfitri, R., \& Mukmin, M. (2019). Pengaruh Pressure, Opportunity, Rasionalization dan Capability Terhadap Kecendrungan Kecurangan Akuntansi (Fraud). Jurnal Akunida, 54-66.

Kusumawardhani, P. (2013). Deteksi Financial Statement Fraud dengan Analisis Fraud Triangle pada Perusahaan Perbankan yang Terdaftar di BEI. Jurnal Akuntansi AKUNESA , 1-20.

Lestari, C. D., Sujana, E., \& Julianto, I. P. (2017). Pengaruh Opportunity, Pressure, Rationalization, dan Perilaku Tidak Etis terhadap Kecendrungan terjadinya Kecurangan. e-journal S1 Ak Univeristas Pendidikan Ganesha, 1-10.

Lestari, N. K., \& Supadmi, N. L. (2017). Pengaruh Pengendalian Internal, Integritas dan Asimetri Informasi pada Kecurangan Akuntansi. E-Jurnal Akuntansi Universitas Udayana, 389-417.

Lubis, A. I. (2010). Akuntansi Keprilakuan. Salemba Empat..

Marliani, M., \& Jogi, Y. (2015). Perspsi Pengaruh Fraud Triangle Terhadap Pencurian Kas. Business Accounting Review, 21-29.

Mulia, M. H., Febrianto, R., \& Kartika, R. (2017). Pengaruh Moralitas Individu dan Pengendalian Internal terhadap Kecurangan: Sebuah Studi Ekspperimental. Jurnal Akuntansi dan Investasi , 198-208.

Nurlaeliyah, S., \& Anisykurlillah, I. (2017). Analysis of Factors Affecting The Tendency of Accounting Fraud with An Ethical Behavior As Intervening Variable. Accounting Analysis Journal , 299-311.

Nwanyanwu, L. A. (2018). Accountant's Ethics and Fraud Control in Nigeria: The Emergence of a Fraud Control Model. Journal of Accounting, Finance and Auditing , 130-150.

Pamungkas, I. D. (2014). Pengaruh Religiusitas dan Rasionalisasi dalam Mencegah dan Mendeteksi Kecendrungan Kecurangan Akuntansi. Jurnal Ekonomi dan Bisnis, 52-53.

Pasaribu, E. M., \& Wijaya, S. Y. (2017). Implementasi Teori Atribusi untuk Menilai Perilaku Kecurangan Akuntansi. Ekonomi dan Bisnis , 41-65.

Pasaribu, R. B., \& Kharisma, A. (2018). Fraud Laporan Keuangan dalam Perspektif Fraud Triangle. Jurnal Reiset Akuntansi \& Keuangan , 53-65.

Pradipta, A., \& Bernawati, Y. (2019). The Influence of Pressure, Opportunity, Rationalization and Ethical Value on the Accounting Fraud Tendency. Sustainable Business Accounting and Management Review , 63-71. 
Pristiyanti, I. R. (2012). Persepsi Pegawai Instansi Pemerintah Mengenai Faktor-Faktor yang Mempengaruhi Fraud di Sektor Pemerintahan. Accounting Analysis Journal , 1-13.

Putra, Y. H. (2010). Praktik Kecurangan Akuntansi dalam Perusahaan. Jurnal Akuntansi (e-journal), 10.

Roden, D. M., Cox, S. R., \& Kim, J. Y. (2016). The Fraud Triangle As A Predictor of Corporate Fraud. Academy of Accounting and Financial Studies Journal, 80-90.

Romney, M. B., \& Steinbart, P. J. (2014). Accounting Information Systems. Jakarta Selatan: Salemba Empat.

Said, J., Alam, M. M., Ramli, M., \& Rafidi, M. (2017). Integrating Ethical Values into Fraud Triangle Theory in Assesing Employee Fraud: Evidence from the Malaysian Banking Industry. Journal of International Studies , 170-184.

Sekaran, U. (2006). Research Methods For Business. Salemba Empat.

Setiawan, R. R. (2016). Pengaruh Penerapan Sistem Pengendalian Intern Kas, Implementasi Good Corporate Governance dan Ketaatan Aturan Akuntansi terhadap Fraud pada Perusahaan BUMN di Kota Pekanbaru. JOM Fekon , 1-14.

Sugiharto. (2005). BUMN Indonesia: isu, kebijakan, dan strategi. Jakarta: Elex Media Komputindo.

Sujarweni, V. W. (2020). Metodologi Penelitian Bisnis \& Ekonomi. Pustakabarupress.

Sujeewa, G. M., Yajid, M. S., Khatibi, A., Azam, S. M., \& Dharmaratne, I. (2018). Fraud Triangle Theory-Integrating Ethical Values of Employees. International Journal of Business, Economic and Law, 52-55.

Sukirman, \& Sari, M. P. (2013). Model Deteksi Kecurangan Berbasis Fraud Triangle. Jurnal Akuntansi dan Auditing, 199-223.

Suryandari, N. P., Wahyuni, M. A., \& Julianto, I. P. (2019). Pengaruh Tekanan, Kesempatan, Rasionalisasi (Triangle) dan Efektivitas Penerapan Pengendalian Internal terhadap Tindak Kecurangan (Fraud). JIMAT (Jurnal Ilmiah Mahasiswa Akuntansi) Universitas Pendidikan Ganesha, 1-8.

Triatmoko, H., \& Nugraheni, N. K. (2017). Analisis Faktor-Faktor yang Mempengaruhi Terjadinya Financial Statement Fraud: Perspektif Diamond Fraud Theory. Jurnal Akuntansi dan Auditing , 118-143.

Trihargo, G. (2016). Survai Fraud Indonesia. ACFE Indonesia Chapter.

Trisna Dewi, N. L., Anggariyani, M. P., Septyastini, I. D., Gayatri, N. M., Sudiari, K. D., \& Andika, K. D. (2018). Fraud Triangle di Sektor Pemerintahan. Jurnal Ilmiah Akuntansi dan Humanika, 157-162.

Umar, H. (2008). Desain Penelitian MSDM dan Perilaku Karyawan. Rajagrafindo Persada.

Upperline.id. (2019). Kasus Suap Krakatau Steel dan Catatan Kelam BUMN. Upperline Media Korporasi Indonesia.

Urumsah, D., Wicaksono, A. P., \& Hardianto, W. (2018). Pentingkah Nilai Religiuditas dan Budaya Organisasi untuk Mengurangi Kecurangan? Jurnal Akuntansi Multiparadigma JAMAL , 156-172.

Velasquez, M. G. (2006). Business Ethics. Pearson Education International.

Wicaksono, A. P., \& Urumsah, D. (2016). Factors Influencing Employees to Commit Fraud in Workplace Empirical Study in Indonesia Hospitals. Asia Pasific Fraud Journal , 1-18.

Zahara, A. (2017). Pengaruh Tekanan, Kesempatan, dan Rasionalisasi terhadap Tindakan Kecurangan (Fraud). WRA , 1-16. 